\title{
Impact of Biomedical Waste on City Environment: Case Study of Pune, India.
}

\author{
Dr. Anjali Acharya ${ }^{1}$, Dr. Vasudha Ashutosh Gokhale ${ }^{2}$, Deepa Joshi ${ }^{3}$ \\ ${ }^{I}$ (Institute for Excellence in Higher Education Bhopal M.P. India) \\ ${ }^{2}$ (B.N. College of Architecture, University of Pune, India) \\ ${ }^{3}$ (Institute for Excellence in Higher Education Bhopal M.P. India)
}

\begin{abstract}
Indian cities are facing problem of Biomedical waste management in the wake of urban development. The number of healthcare facilities is increasing day by day resulting in large-scale generation of bio medical waste. It has been observed that inadequate disposal of biomedical waste is creating highly unhygienic environment and posing serious heath threat for inhabitants. Present paper discusses the issue of biomedical waste management from a wider perspective with special emphasis on chemical waste which is one of the most hazardous wastes in present context. Various types of biomedical waste with reference to generation, handling and disposal practices are presented. It includes study and analysis of the parameters which affect the quality of environment to explore their impact on city environments. The current practices of handling such waste is presented based on a study conducted in city of Pune, which is the second largest city in the state of Maharashtra, India. It is aimed to put forth the importance of adequate handling and treatment of biomedical waste with reference to healthy and hygienic living environment for inhabitants to live in.
\end{abstract}

Keywords: Biomedical, Chemical, Maharashtra, Radioactive, Pune.

\section{INTRODUCTION}

Some $25 \%$ of biomedical waste is hazardous which adversely affect city environment allover the world particularly developing countries are most at risk due to poor waste management. Healthcare facilities in an urban area are designed as a place for patients for diagnosis, analysis and treatment of medical problems. It houses a number of complex activities where generation of solid waste is unavoidable. This solid waste referred as "healthcare waste" which include all waste, biological or non-biological that is discarded and will never be used again [1,2]. Medical waste can be classified in three groups: medical waste, infectious waste and domestic waste. "Medical waste" refers to materials accumulated as a result of patient diagnosis, treatment or immunization of patients. "Infectious waste" refers to the portion of medical waste that is in contact with a patient who has infectious disease and it is capable of producing an infectious disease. Majority of cases medical waste is considered to be infectious waste, if medical waste and other waste are not collected separately. If all waste is mixed then the hospital waste is presumed to be infectious waste. Of the total amount of waste generated by health-care activities, about $80 \%$ is general waste. The remaining $20 \%$ is considered hazardous material that may be infectious, toxic or radioactive (fig.1). Every year an estimated 16000 million injections are administered worldwide, but not all of the needles and syringes are properly disposed of afterwards [3].

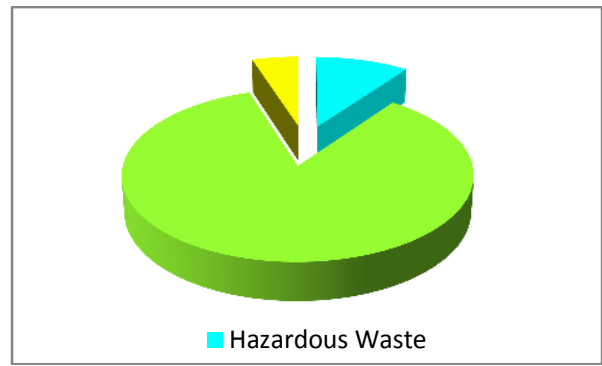

Figure.1 Types of Biomedical Waste.

II.

BIOMEDICAL WASTE

Health-care waste contains potentially harmful microorganisms which can infect hospital patients, health-care workers and the general public. Health-care waste includes all the waste generated by health-care establishments, research facilities, and laboratories. In addition, it includes the waste originating from "minor" or "scattered" sources--such as that produced in the course of health care undertaken in the home (dialysis, insulin injections, etc.). There are five categories of healthcare waste as shown below: 


\section{Categories of health care waste:}

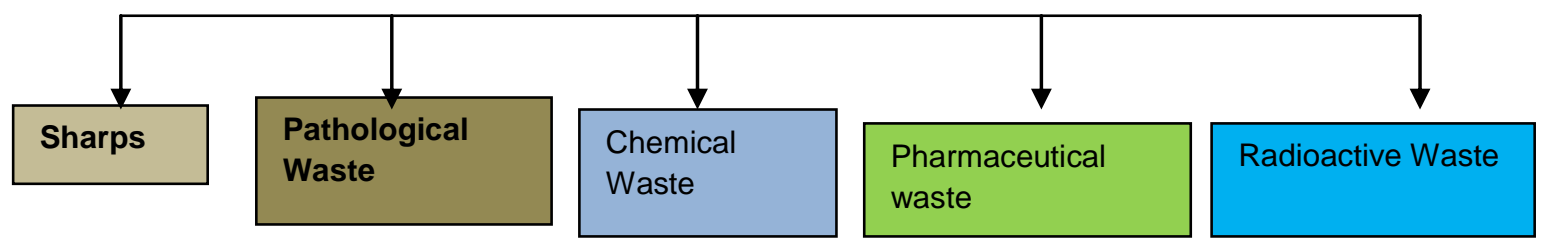

Infectious waste is material suspected to contain pathogens (bacteria, viruses, parasites or fungi) in sufficient concentration or quantity to cause disease in susceptible hosts. This category includes waste contaminated with blood or other body fluids, cultures and stocks of infectious agents from laboratory work, waste from infected patients in isolation wards; dressings, bandages and other material contaminated with blood or other body fluids which is Infectious because it contains bacteria, viruses, parasites or fungi. Sharps are the Hhypodermic, intravenous or other needles; auto-disable syringes; syringes with attached needles; infusion sets; scalpels; pipettes; knives; blades; broken glass. Pathological waste contains human tissues, organs or fluids; body parts; unused blood products. Chemical Waste containing chemical substances (e.g. laboratory reagents; film developer; disinfectants that are expired or no longer needed; solvents; waste with high content of heavy metals, e.g. batteries; broken thermometers and blood pressure gauges). Pharmaceuticals that are expired or no longer needed; items contaminated by or containing pharmaceuticals; cytotoxic waste containing substances with genotoxic properties waste containing cytostatic drugs (often used in cancer therapy) genotoxic chemicals). Radioactive: Waste containing radioactive substances (e.g. unused liquids from radiotherapy or laboratory research; contaminated glassware, packages, or absorbent paper; urine and excreta from patients treated or tested with unsealed radionuclides; sealed sources [4].

Generation of waste depends on numerous factors such as type of healthcare facility, specialization, proportion of reusable items employed in hospital, and proportion of patients treated on a day-care basis. Hospitals and clinics are the only one source of infectious waste generation which is heterogeneous mixtures composed of general refuse, laboratory and pharmaceutical chemicals and their containers, and pathological wastes. As a result, some infectious wastes do not separate from general waste and may pose a threat to the environment.

\section{ENVIRONMENTAL CONSEQUENCES}

Improper management of health care waste can have both direct and indirect health consequences for health personnel, community members and to the environment Indirect consequences in the form of toxic emissions from inadequate burning of medical waste, or the production of millions of used syringes in a period of three to four weeks from an insufficiently well planned mass immunization campaign. Direct consequences when disposable materials (especially syringes) are intentionally re-used

- $\quad$ Exposed groups and associated risks

- Health-care workers

- Waste handlers

- Scavengers retrieving items from dumpsites

- Children who may come into contact with contaminated waste

- Communities living near landfill and waste sites or near treatment facilities

- Local populations affected by the utilization of products recycled from health care waste and the reuse of untreated medical equipment.

\section{HEALTHCARE WASTE Risk WORLDWIDE}

Management of healthcare waste is very important for keeping living environment healthy. It has been reported that in UK in period of 96 to 2004, 2140 people got occupational exposures to blood borne viruses. It has been found that $21 \%$ of the injuries occurred during the disposal process. As per study in Mexico city out of 69 interviewed waste handlers 34\% (13) reported 22 needle stick injuries between them during the first 12 months and $96 \%$ had seen needles and syringes in waste. In Pakistan on average scavenger boys who were going through medical waste, for collection and resale, experienced three to five needle stick injuries a day .

Dozen of children in Sadri City, largest suburb of Baghdad, have been admitted to hospitals with symptoms of infectious diseases due to contact with waste. Low income households are more likely to live close to waste sites resulting in more direct contact with health care waste. In India more than $30 \%$ of the injections administered each year were carried out using re-used or inadequately sterilized medical equipment and that nationally, $10 \%$ of health care facilities sold used syringes to waste pickers. Research suggests that population living within $3 \mathrm{~km}$ of old incinerators saw an increase of 3.5\% in the risk of contracting cancer [5]. 


\section{ChEMICAL WASTES}

This type of waste in generated in laboratories, disinfection operations and central supply which contain highly toxic agents and solvents. This waste must be classified just after collection and separated according to type:

- Noxious chemical substances in water solutions.

- Non halogenated mixtures of laboratory solvents and organic compounds

- Halogenated mixtures of solvents and organic compounds.

- Mixture of solid metals, non metals, oxides, anhydrides and salt.

- Volatile heavy metals

- Expired laboratory reagents.

The types of hazardous chemicals used most commonly in maintenance of health-care centers and hospitals and the most likely to be found in waste are as follows:

\section{Formaldehyde}

Formaldehyde is a significant source of chemical waste in hospitals. It is used to clean and disinfect equipment (e.g. haemodialysis or surgical equipment), to preserve specimens, to disinfect liquid infectious waste, and in pathology, autopsy, dialysis, embalming, and nursing units.

\section{Photographic chemicals}

Photographic mixing and developing solutions are used in $\mathrm{X}$-ray departments.

The mixer usually contains 5$10 \%$ hydroquinone, $1-5 \%$ potassium hydroxide, and less than $1 \%$ silver. The developer contains approximately $45 \%$ glutaraldehyde. Acetic acid is used in both stop baths and mixer solutions.

\section{Solvents}

Wastes containing solvents are generated in various departments of a hospital, including pathology and histology laboratories and engineering departments. Solvents used in hospitals include halogenated compounds, such as methylene chloride, chloroform, trichloroethylene, and refrigerants, and nonhalogenated compounds such as xylene, methanol, acetone, isopropanol, toluene, ethyl acetate, and acetonitrile.

Organic chemicals: Waste organic chemicals generated in health-care facilities include:

Disinfecting and cleaning solutions such as phenol-based chemicals used for scrubbing, perchlorethylene used in workshops and laundries.

Oils such as vacuum-pump oils are used engine oil from vehicles, particularly if there is a vehicle service station on the hospital premises.

Inorganic chemicals: Waste inorganic chemicals consist mainly of acids and alkalis (e.g. sulfuric, hydrochloric, nitric, and chromic acids, sodium hydroxide and ammonia solutions). They also include oxidants, such as potassium permanganate $(\mathrm{KMnO} 4)$ and potassium dichromate $(\mathrm{K} 2 \mathrm{Cr} 2 \mathrm{O} 7)$, and reducing agents, such as sodium bisulphate (NaHSO3) and sodium sulphate (Na2SO3) [6].

TABLE 1 - MOST COMMON GASES USED IN HEALTH CARE

\begin{tabular}{|l|l|}
\hline \multicolumn{1}{|c|}{$\begin{array}{c}\text { Applications- } \\
\text { Anesthetic gases: } \\
\text { nitrous oxide, volatile halogenated hydrocarbons (such as } \\
\text { halothane, isoflurane, and enflurane), which have largely } \\
\text { replaced ether and chloroform. }\end{array}$} & $\begin{array}{l}\text { In hospital operating theatres, during childbirth in maternity } \\
\text { hospitals, in ambulances, in general hospital wards during painful } \\
\text { procedures, in dentistry, for sedation, etc. }\end{array}$ \\
\hline Ethylene oxide & $\begin{array}{l}\text { For sterilization of surgical equipment and medical devices, in } \\
\text { central supply areas, and, at times, in operating rooms. }\end{array}$ \\
\hline $\begin{array}{l}\text { Oxygen } \\
\text { Stored in bulk tank or cylinders, in gaseous or liquid form, or }\end{array}$ & Inhalation supply for patients. \\
\hline Compressed air & $\begin{array}{l}\text { In laboratory work, inhalation therapy equipment, maintenance } \\
\text { equipment, and environmental control systems. }\end{array}$ \\
\hline
\end{tabular}




\section{GENO-TOXIC PRODUCTS USED IN HEALTH CARE}

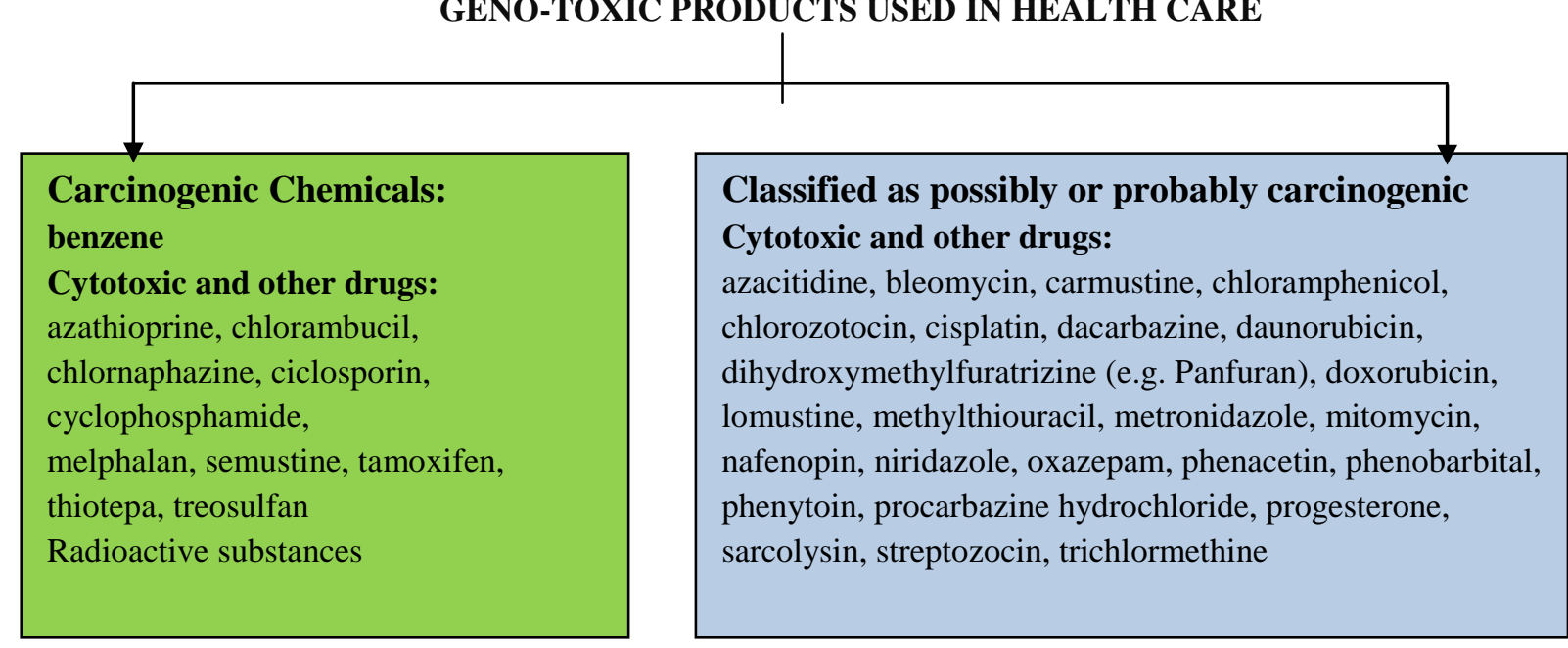

\section{Storage Of Chemical Waste}

This must be performed in compliance with safety precautions, water tight containment tanks and separated from other type of wastes. Following are the hazards caused by inadequate storage:

- Mercury trapped in porous sinks that continues to vaporize.

- Improper storage of perchloric acid that might result in an explosion.

- Azides that combine with the metals $(\mathrm{Cu}, \mathrm{Pb})$ or Ammonia in plumbing systems and may form explosive combinations when dry.

- Organic solvents that continues to vaporize.

- Unsafe storage of flammable substances.

Table 2

\begin{tabular}{|c|c|c|}
\hline $\begin{array}{l}\text { Chemical Disinfectants } \\
\text { Isopropyl alcohol } \\
\text { Ammonia } \\
\text { Sodium hypoclorite } \\
\text { Iodine } \\
\text { Phenolics } \\
\text { Quaternary ammonia compounds } \\
\text { Glutaraldehyde } \\
\text { Lysoform } \\
\text { Ethylene oxide(residues) }\end{array}$ & $\begin{array}{l}\text { Cleaning, disinfection and sterilization } \\
\text { operations }\end{array}$ & $\begin{array}{l}\text { Irritation, necrosis or burns to eye, } \\
\text { mucous membrane and skin Coughing, } \\
\text { chest tightness, increased heart rate. } \\
\text { Pulmonary edema and pneumonitis. } \\
\text { Toxic if inhaled and on skin contact. }\end{array}$ \\
\hline Antineoplastic drugs & Drug preparation and administration & $\begin{array}{l}\text { Potential human carcinogenesis and } \\
\text { teratogenicity. Local tissue necrosis } \\
\text { and mucous membrane reactions. } \\
\text { Nausea, allergic reactions, cough and } \\
\text { hair loss }\end{array}$ \\
\hline Pharmaceuticals & Drug administration & Local allergic reactions \\
\hline Freon & $\begin{array}{l}\text { Pathology laboratory Central supply } \\
\text { department }\end{array}$ & Eye and skin irritation or sensitization. \\
\hline Mercury & $\begin{array}{l}\text { Much hospital equipments. Dental } \\
\text { amalgams. }\end{array}$ & $\begin{array}{l}\text { Severe respiratory irritation, digestive } \\
\text { disturbance, renal damage. Dermatitis. }\end{array}$ \\
\hline Methyl metacrilate & Operating rooms & $\begin{array}{l}\text { Irritation to eye, skin an d mucous } \\
\text { membranes. Affects central nervous } \\
\text { system. }\end{array}$ \\
\hline Peroxyacetic Acid & $\begin{array}{l}\text { Laboratories, central supply, patient } \\
\text { care units. }\end{array}$ & $\begin{array}{l}\text { String eye, skin and mucous membrane } \\
\text { irritant. Promotes skin tumors. }\end{array}$ \\
\hline $\begin{array}{l}\text { Colvents: } \\
\text { Methyl ethyl ketone } \\
\text { Acetone } \\
\text { Benzene } \\
\text { Chloroform } \\
\text { Ether } \\
\text { Dioxane } \\
\text { Xylene } \\
\text { Ethyl alcohol } \\
\text { Methyl alcohol }\end{array}$ & $\begin{array}{l}\text { Laboratories. Also present in cleaning } \\
\text { agents in house keeping. Glues and } \\
\text { paints in maintenance. }\end{array}$ & $\begin{array}{l}\text { Nervous system depressants. } \\
\text { Headaches, dizziness, weakness, } \\
\text { nausea. } \\
\text { Irritation of eye and upper respiratory } \\
\text { tract. } \\
\text { Deflating and dehydration of the skin. } \\
\text { Highly inflammable. }\end{array}$ \\
\hline
\end{tabular}



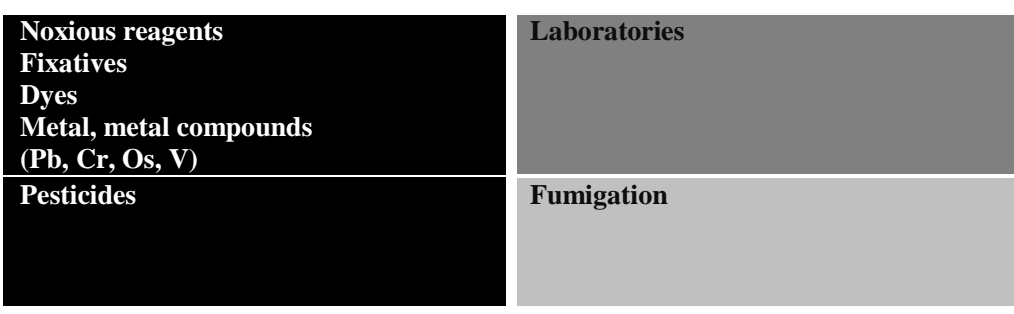

Fumigation

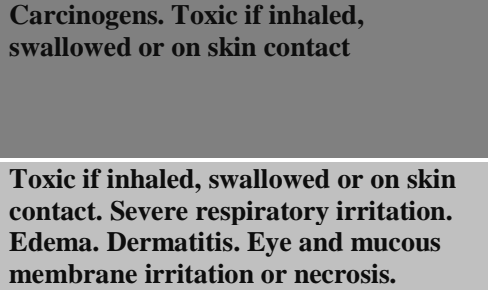

Carcinogens. Toxic if inhaled,

swallowed or on skin contact

Toxic if inhaled, swallowed or on skin Edema. Dermatitis. Eye and mucous membrane irritation or necrosis.

\section{Process OF BIOMEDICAL WASTE MANAGEMENT}

Careful segregation and separate collection of hospital waste is the key to safe, sound management of health-care waste. Segregation can substantially reduce the quantity of health-care waste that requires specialized treatment. In any area that produces hazardous waste hospital wards, treatment rooms, operating theatres, laboratories, etc [7] (fig. 2,3,4).

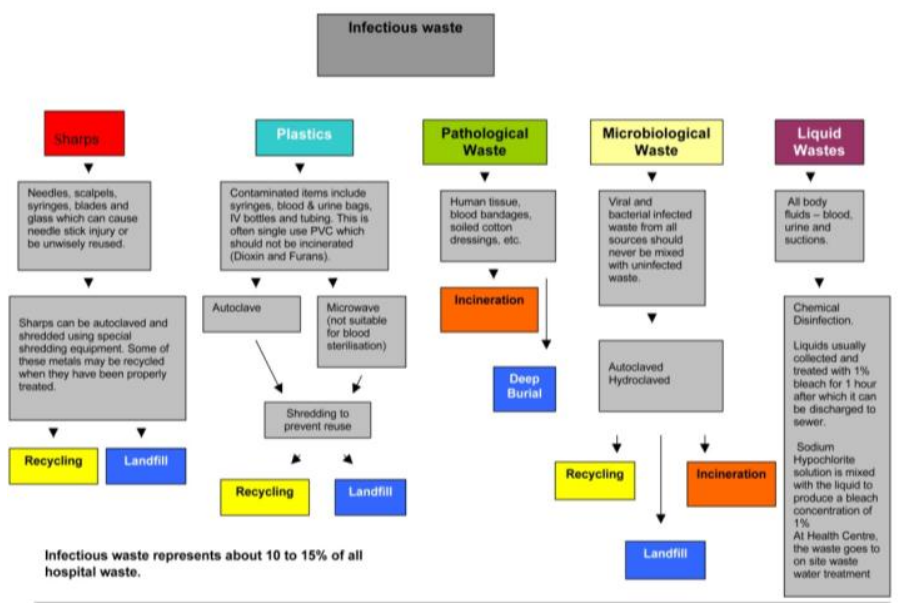

Figure 2. Management of biomedical waste

Source : $[8]$

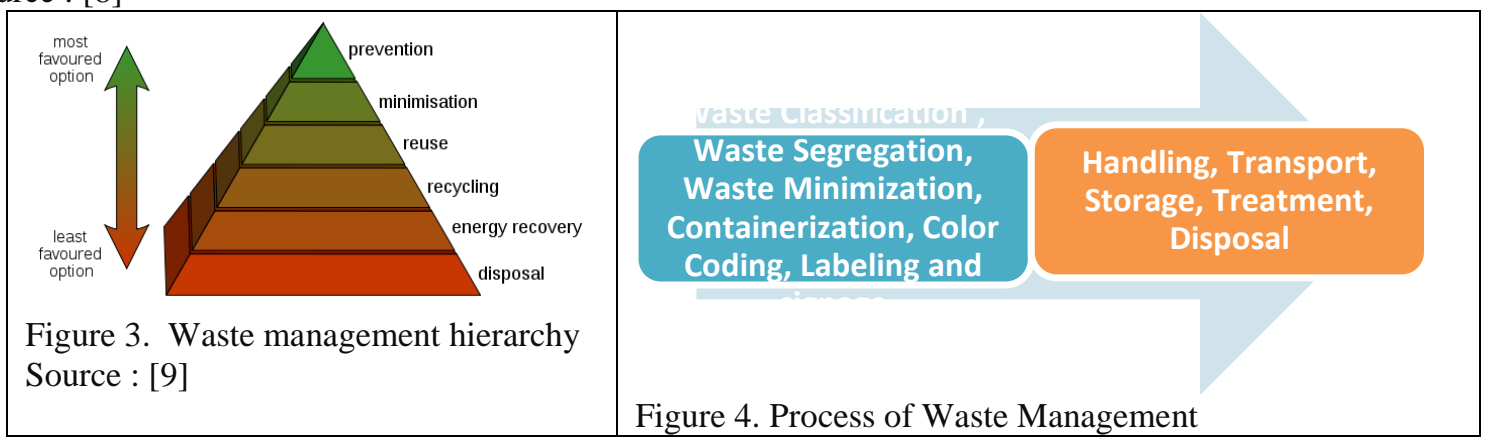

\section{PUNE City: Situational ANALYSIS}

Pune is the eighth largest metropolis in India and the second largest in the state of Maharashtra with a total population 60,49,968 as per 2001 census. The total number of hospitals in Pune Municipal Corporation, Pune Cantonment Board and Pimpri-Chinchwad Municipal Corporations' jurisdiction are 928, which cater for around 3,350 Patients daily [10]. In total, around 3,000 kg of bio-waste is generated in the city, out of this; Corporation- run hospitals generate almost $450 \mathrm{~kg}$ of bio-waste every day. Bio-medical wastes include human anatomical waste like tissues, organs, body parts, as also animal waste, microbiological and biotechnological waste, hypodermic needles, syringes, scalpels, broken glass, discarded medicines, dressing's bandages, catheters, incineration ash, etc. There are more than 34 dispensaries, 14 maternity hospitals and an infectious disease hospital in the city which operate without adequate approval from municipal bodies. From these facilities bio-medical waste is collected and treated at the Kailas Crematorium plant. In total, Pune Municipal Corporation $\{$ PMC $\}$ collects biomedical waste from 764 hospitals, 2,222 clinics, 222 pathology laboratories and 12 blood banks. It has been notices that, only 2,162 clinics in the city have opted for the common biomedical waste treatment facility, located at Kailas crematorium off Raja Bahadur Mill Road. Only 2,162 clinics send their biomedical waste to the treatment facility. Over 6,000 clinics in Pune are operating without adequate arrangement for handling collection and treatment of biomedical waste generate even they are taking advantage 
of available service. Besides out of 697 nursing homes, 107 have not complied the laid norms and majority of the clinics are disposing of waste in an unscientific and hazardous manner. Approximately about 1,200 kg biomedical waste is transported every day to Taloja, Talegaon and Satara located for over $140 \mathrm{~km}$ from Pune [11].

While city hospitals and clinics generate $2 \mathrm{~kg}$ metric tones of bio medical waste daily, there are host of others who are not registered under the scheme (fig.5). A total of 588 hospitals, 1,893 clinics, 196 pathology laboratories and 14 blood banks are registered under the scheme, Nearly 5,000-7,000 medical practitioners in Pune (including Homoeopathic, Ayurvedic, Unani, and other practitioners), barely about a 1,000 are registered under the bio-medical waste common disposal facility.

As per the Medical Waste (management and handling) Rules, 1998 and Amendment, it is obligatory for all clinical establishments to get this authorization. It is also compulsory to submit an undertaking and treat biomedical waste at MPCB-approved units, as per the Act.
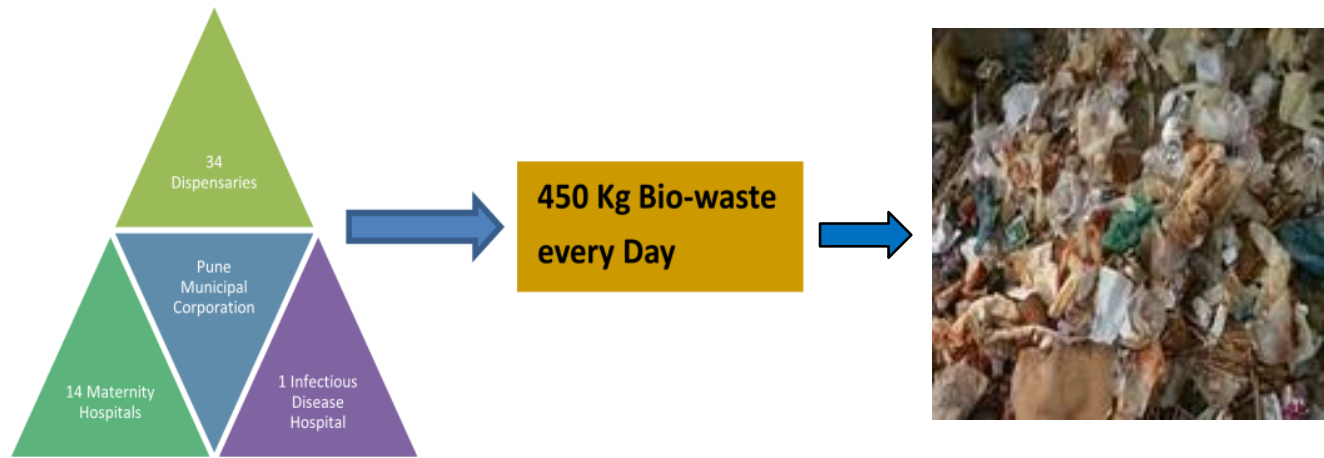

Figure 5. Biomedical Waste Generation.

A survey conducted in 10 hospitals from Pune city revealed that more than $55 \%$ of employees are not aware of the adequate handling, collection and treatment of biomedical waste. About $62 \%$ respondents does not found it a serious issue and about $45 \%$ of owner of are found to be ignorant.

\section{DISCUSSION}

Hospitals and clinics in Pune are becoming a major threat to the public as they are not following the biomedical waste management rules meant to prevent contamination and spreading of diseases. City hospitals are flouting rules pertaining to biomedical waste management at will. While the law prescribes for an authorized agency to handle the hazardous biomedical waste, several hospitals are entrusting the waste to private parties or even dumping them in the PMC garbage bins. It goes without saying that such carelessness can not only cause health issues but also lead to the spread of communicable diseases. The Bio Medical Waste Management Act The Bio Medical Waste Management Act 1988 states that all hospital should eliminate their medical wastes by installing an incinerator at the hospital premises. However installing an incinerator is an expensive affair that many small hospitals and clinics cannot afford. This paved the way for amendment in 1998 which called for a common registered authority for handling biomedical wastes. Most of the clinics and hospitals are not even aware of the rules as revealed from survey conducted. The management has no qualms in admitting that they dump biomedical waste along with other garbage in PMC bins. It has been observed that dustbins around the hospitals are filled with syringes, blood lined cottons and other wastes. As per the law, hospitals should have red, yellow, blue and black colored boxes in which different type of wastes depending upon their toxicity are to be segregated and handed over to the agencies. Medical waste has to be packed safely before handing it over to these waste management plants. Clearly hospitals and clinics are not blatantly fluting rules.

\section{CONCLUSION}

Traditionally, hospital wastes have been disposed of with the municipal wastes in landfills. However, since the late 1980's, the spreading trend of immunodeficiency virus (HIV), hepatitis B virus (HBV) and other agents associated with blood bone diseases has raised public awareness and concerns of the disposition of medical waste. As a result, medical waste is required to be treated in a special way and not to be mixed with municipal waste. Proper medical waste management requires special treatment of medical waste such as incineration or hazardous waste landfill facilities [12]. Former studies have shown that the best available technology for disposing of medical waste is incineration. Infectious waste should go into yellow leak-proof plastic bags or containers. Bags and containers for infectious waste should be marked with the international infectious substance symbol Chemical waste consists of discarded solid, liquid, and gaseous chemicals, for example from diagnostic and experimental work and from cleaning, housekeeping, and disinfecting procedures. Pharmaceutical waste includes expired, unused, spilt, and contaminated pharmaceutical products, drugs, 
vaccines, and sera that are no longer required and need to be disposed of appropriately. Small amounts of chemical or pharmaceutical waste may be collected together with infectious waste. Large quantities of chemical waste should be packed in chemical-resistant containers. The identity of the chemicals should be clearly marked on the containers: hazardous chemical wastes of different types should never be mixed. The proper collection of hospital waste will reduce the volume of infectious wastes and consequently the cost of treatment. Considering the scale of biomedical waste generated in Indian cities like Pune is imperative to take this issue at top most priority basis. Adequate biomedical waste management is the solution to safeguard city environment and provide a healthy, hygienic living environments for the city dwellers.

\section{REFERENCES}

[1] Rutala, A.W., Mayhall, G., Medical Waste, Infection Control Hospital Epidemiology, pp. 38-48, 1992.

[2] Arian, D.S., A.M. Asce, J., H. B., Arian, L., Mcmurray, T. D., Hospital Solid Waste Management A Case Study, J. Environ. Eng. Div., August, 741-753, 1980.

[3] www.bbic-network.org.

[4] Pruss, E. Giroult, P. Rushbrook, .Safe management of waste from health-care activities, WHO Library Cataloguing-in-Publication Data, 1999.

[5] http://www.healthcarewaste.org

[6] Li, C., Fu-Tien, J., Physical and Chemical Composition of Hospital Waste, Infection Control and Hospital Epidemiology, 14(3), 145, 1993.

[7] Guerquin, F., Treatment of Medical Wastes, Waste, Manag. Disp. J., 1995, 115-117.

[8] biomedical waste management aashim.wordpress.com

[9] http://en.wikipedia.org/wiki/Waste_management

[10] www.punecorporation.org

[11] www.indianexpress.com

[12] EPA. Guide for Infectious Waste Management, EPA/ 530-SW-86-014, 1986. 